\title{
Review of Survey activities 2018
}

\author{
Flemming G. Christiansen ${ }^{* 1}$ \\ Deputy Director, Geological Survey of Denmark and Greenland (GEUS)
}

PREFACE | OPEN ACCESS

GEUS Bulletin Vol 43 | e2019430001 | Published online: 07 August 2019

https://doi.org/10.34194/GEUSB-201943-00-01

Every four years the Geological Survey of Denmark and Greenland (GEUS) develops and implements new strategies to ensure that we are able to help meet the ever-changing challenges that face society. In 2018 these discussions were shaped by important issues like climate change and climate adaptation, and their consequences for our use of energy, minerals and water resources.

As part of this strategic focus, GEUS introduced a new publication strategy in 2018 that seeks to increase our publication rate of high impact science, and to gain more visibility within the international scientific community and the media. Many different tools will be applied to make such a long-term cultural change possible, including modernisation of GEUS' own publication series.

It is therefore very promising to see this issue of Review of Survey activities (ROSA) published in a modernised bulletin. The GEUS Bulletin is an international open-access publication with peer-reviewed papers. For the first time ROSA is published online only and all papers can be downloaded shortly after completion. Papers are easily identified and cross-referenced with DOIs (Digital Object Identifiers), and keywords and publication history are provided. In addition, there are better possibilities for provision of online supplementary data to document large datasets. This new format will hopefully allow for a much quicker and more efficient distribution and thereby attract higher interest from the media and society.

This issue of Review of Survey activities includes 16 papers covering many different activities in Denmark, Greenland and beyond. Six papers are on Denmark, eight on Greenland, and two on other themes. Due to the new format, several of the papers are slightly longer than in previous years, where the four-page limit sometimes made it difficult to fully document and discuss key results.

\section{Activities in Denmark}

GEUS activities and research in Denmark cover a wide range of topics within our specific programme areas: data, water, energy, mineral resources, nature and climate.
Our strong focus on climate change and climate adaptation is reflected in several papers. One very interesting paper on sea-level rise in Denmark combines the Representative Concentration Pathway 4.5 scenario ("Paris Agreement" climate pathway) with local reconstructions of glacio-isostatic rebound curves to calculate future differences in sea level between Skagen, Copenhagen and Esbjerg. Another paper presents a statistical discussion on how models of precipitation and temperature projections can be downscaled from coarse meteorological grids to the much more detailed grids that GEUS is using in our Danish National Water Resources Model.

Understanding properties of reservoir sandstones and their fluids is very import for predicting production models of petroleum and geothermal energy, or for Carbon Capture and Storage (CCS). One paper provides an analysis of porosity-preserving microquartz coatings in deeply buried Jurassic sandstones in the Danish Central Graben and the implications for production parameters. Another paper gives a first classification of different brine types in Mesozoic reservoirs in areas with a geothermal potential onshore Denmark. This is very important for evaluating the scaling risk prior to new drilling.

After many years of unsuccessful onshore petroleum exploration in Denmark and the expectation of only limited potential in this area, the Danish Government finally decided in February 2018 to halt all further petroleum exploration on- and nearshore. One paper describes the exploration history in the region since the last major study was completed in 1987, and reviews the various exploration play types. Much of the data and results from this decades-long period of onshore exploration are very important for developing a more detailed understanding of the potential for geothermal energy and CCS in many parts of Denmark.

The last Danish paper provides new information on the deeply incised and partly sediment-filled channels in Storebælt using radiocarbon ages, and thereby suggests new models for the history of water connections between Kattegat and the Baltic Sea. 


\section{Activities in Greenland}

Once again, there was a high level of activity in Greenland in 2018. GEUS continues to focus on climate projects related to the PROMICE monitoring programme. Furthermore, there are many traditional studies on petroleum and mineral resources, and some new initiatives on geohazards.

Two papers are on PROMICE services. The first provides a complete mass balance for the Greenland ice sheet between 1995 and 2015. Data were obtained by repeated measurements of altitude and ice thickness circumscribing the ice sheet at $1708 \mathrm{~m}$ altitude - a $5415 \mathrm{~km}$ long perimeter survey. The second paper provides an update of the annual calving front lines for 47 marine outlet glaciers distributed throughout Greenland. The net area change of these glaciers is significant over the period 1999-2018 and these data will be important for mass balance calculations.

Mineral exploration by industry has remained relatively low in recent years, and most petroleum activities have stopped since all supermajors and majors have left Greenland. It is, however, important to prepare for a future when prices of the most important commodities eventually rise again. One paper provides interesting results on $\mathrm{U}-\mathrm{Pb}$ dating of titanite in Paleogene sandstones in a volcanic terrane in East Greenland. This can be very important for constraining sources of sedimentary rocks and can help to date the precipitated titanite. Another paper is on the Liverpool Land Basement High (LLBH), which could offer a large and interesting analogue for fractured basement reservoirs that have recently attracted interest in petroleum exploration in several places in the North Atlantic. LLBH is well exposed and provides good possibilities for developing 3D models of faults, fractures and veins and their connectivity. Sampling may provide information on their origin, e.g. timing and fluid conditions.

Spaceborne remote sensing data can be a fast and costeffective tool in early mineral exploration. A case study from Wollaston Forland, North-East Greenland is presented. They compare data from ASTER and Sentinel-2 to discriminate between various lithological units. ASTER seems to give the best results for this mapping purpose. Glacial rock flour has recently been suggested as a natural fertiliser that could be used especially in tropical areas with poor soil quality. One paper describes mapping and sampling of such deposits in Lake Tasersuaq, West Greenland.

On 17 June 2017 a large landslide in Karrat Fjord triggered a devastating tsunami. In the weeks that followed, GEUS was deeply involved in coordinating information and knowledge from many dedicated scientists in order to advise the Greenland authorities. It soon became evident that there was a strong need for a better understanding of the risk of landslide-generated tsunamis across Greenland. It is particularly important to understand how an apparent increase in the number of events relates to climate change, and how geology, terrain and local climate control the distribution of risk area. In 2018, GEUS completed a screening study of the risk of major landslides. One paper gives an overview of historical records and applied mapping and satellite techniques that have been used to map the occurrence of more than 500 landslides in Greenland. Another paper documents a multidisciplinary case study of a landslide in 2018 in the Karrat Fjord, using seismological data, geological data, optical satellite images and radar satellite data to describe activity before and during the event.

\section{Other activities}

Internationally, GEUS collaborates with a number of research institutes on a wide variety of projects, including broader thematic studies and the development of new techniques and databases.

Based on our own high-quality analytical techniques, GEUS has worked with provenance studies for several decades and we have compiled large amounts of zircon ages and other types of provenance data in Greenland, the North Atlantic and the North Sea. These data are useful for researchers and industry, and so GEUS and the Norwegian Petroleum Directorate (NPD) have collaboratively launched an online database, the so-called North Atlantic Provenance Database, to collate these regional data. One of the papers in this issue provides an introduction to a number of the visualisation and statistical tools available in the database, which will be developed further in the coming years.

The last paper is on the use of drones equipped with multisensors for geological mapping and mineral exploration. The development of light weight magnetic and hyperspectral tools together with a high quality positioning system made in collaboration with several European partners is described, together with a presentation of preliminary results from two mining areas in Finland.

\section{How to cite}

Christiansen, F.G. 2019: Review of Survey Activities 2018: Preface. Geological Survey of Denmark and Greenland Bulletin 43, e2019430001.https://doi.org/10.34194/GEUSB-201943-00-01

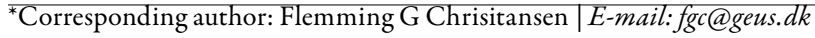

${ }^{1}$ Geological Survey of Denmark and Greenland (GEUS), Øster Voldgade 10, DK-1350, Copenhagen K, Denmark.
} 